\title{
Framing Edukasi Body Positivity Versi Pesohor Sebagai Upaya Penggeseran Nilai Kesusilaan
}

\author{
Elyan Nadian Zahara \\ Departemen Ilmu Komunikasi, Program Pascasarjana, Universitas Indonesia \\ Gedung IASTH Lt. 6, Kampus UI Salemba, Jl. Salemba Raya 4 Jakarta 10430 \\ Corresponding author: elyannadianzahara@gmail.com
}

\begin{abstract}
The study aims to analyze tirto.id as a reputable medium taking a position as a business institution rather than a societal institution, in preaching a discurity around pornography. Researchers used qualitative approaches as well as Fairclough Discourse Analysis as methods. In analyzing the frame of news issues as well as the ideologies that the media brings, researchers use framing theories, ideological concepts, and decency. The results of this study found two framings, namely the analysis of "Tara's Photo as a form of Body Positivity Education" and "Kominfo That Neglects To See Context". The framing suggests the ideology held by tirto.id is not in line with Pancasila's second glare as a state ideology and has the potential to shift the value of decency so that similar actions are considered commonplace in the later life. The substance of this research provides input to the audience so that the understanding that reputable media is not synonymous with idealism as a societal institution, therefore the critical attitude of the reader is needed in reading the discursion presented by the media in the news Keywords: Analysis Of Critical Discourse; Body Positivity; Framing; Pornography; Tirto.Id
\end{abstract}

\begin{abstract}
Abstrak
Bahasa merupakan praktik kekuasaan yang menjadi perantara penyampaian ideologi kepada orang lain. Media memiliki kuasa untuk mengkonstruksi realita melalui teks-teksnya. Melalui penelitian ini, peneliti bermaksud mencari tahu bingkai yang digunakan tirto.id sebagai portal berita online terkemuka di Indonesia, dalam mengkonstruksi realitas pada pemberitaan isu foto tanpa busana Tara Basro awal Maret lalu. Selain itu, peneliti juga bermaksud menginvestigasi implikasi yang menyertainya. Dalam melakukan hal tersebut, peneliti akan menggunakan pendekatan kualitatif, metode analisis wacana Fairclough dengan menggunakan teori ideologi dan konsep framing dan kesusilaan. Hasil penelitian menunjukkan bahwa tirto.id menggunakanan dua framing dalam artikel tersebut, yaitu "Foto Tara sebagai bentuk Edukasi Body positivity" dan "Kominfo yang Abai Melihat Konteks". Framing tersebut menunjukkan ideologi yang dipegang tirto.id, yang bertentangan dengan sila kedua Pancasila sebagai ideologi negara dan berpotensi menggeser nilai kesusilaan sehingga tindakan serupa berpotensi dianggap lumrah di kemudian hari. Kata kunci: Analisis Wacana Kritis; Body positivity; Framing; Pornografi; Tirto.Id
\end{abstract}

\section{Pendahuluan}

Media massa lahir dan tumbuh di dalam masyarakat, sehingga media tidak dapat lepas dari keterkaitan dengan sistem dan praktik sosial yang ada. Media merupakan lembaga komunikasi yang memproduksi dan mendistribusikan informasi serta memiliki dua posisi kelembagaan, yaitu sebagai lembaga kemasyarakatan dan lembaga bisnis (Rusadi, 2015). Posisi media sebagai lembaga kemasyarakatan, media tumbuh dan berkembang selaras dengan kehidupan masyarakat. Media mengemban tugas besar untuk dapat memberdayakan kehidupan masyarakat itu sendiri. Durkheim (Silverblatt, 2004) menyatakan fungsi media sebagai lembaga kemasyarakatan dan berjalan sesuai fungsi seperti keluarga, sekolah, gereja, dan pemerintahan. Di sisi lain, posisi sebagai lembaga bisnis membuat media suka tidak suka mengikuti selera pasar untuk dapat bertahan dan memperoleh keuntungan bagi institusinya. Pada praktiknya, media selalu memiliki kecenderungan dan kedua posisi ini tidak dapat dimainkan secara bersamaan dengan setimbang. Posisi ini pula yang kemudian berperan dalam menentukan ideologi pada media. Hal ini dapat terlihat melalui gaya media dalam mengulas sebuah isu yang berkembang di masyarakat.

Awal Maret 2020, unggahan foto aktris peran Tara Basro di media sosialnya, menjadi 
perbincangan warganet. Pada laman Twitternya, Tara sempat mengunggah foto diri tanpa busana dalam pose duduk menghadap samping sembari menutup bagian intim tubuhnya dengan keterangan: "worthy of love". Di laman akun media sosial Instagram, Tara mengunggah fotonya dengan rambut tergerai, tertawa lepas serta hanya mengenakan pakaian dalam seraya memperlihatkan ketidaksempurnaan bagian perut dan paha. Tara berujar dalam keterangan foto:

"Dari dulu yang selalu gue denger dari orang adalah hal jelek tentang tubuh mereka, akhirnya gue pun terbiasa ngelakuin hal yang sama, mengkritik dan menjelekjelekkan. Andaikan kita lebih terbiasa untuk melihat hal yang baik dan positif, bersyukur dengan apa yang kita miliki, dan make the best out of it daripada fokus dengan apa yang tidak kita miliki. Setelah perjalanan yang panjang, gue bisa bilang kalau gue cinta sama tubuh gue dan gue bangga akan itu. Let yourself bloom," (https://www. instagram.com/tarabasro/, 3 Maret 2020)

Foto Tara mengundang reaksi pro dan kontra dari masyarakat, hingga akhirnya Tara menghapus unggahannya di Twitter, namun tidak demikian dengan unggahan di Instagram. Hal tersebut disikapi oleh Kementerian Komunikasi dan Informatika (Kominfo) melalui Pelaksana Tugas (Plt) Kepala Biro Humas, Fernandus Setu, sempat mengeluarkan pernyataan bahwa foto Tara Basro di Twitter melanggar Pasal 27 ayat 1 Undang-undang Nomor 11 Tahun 2008 tentang Informasi dan Transaksi Elektronik (UU ITE) karena dianggap mengandung unsur pornografi. Beberapa hari kemudian pernyataan tersebut dibantah oleh Menteri Komunikasi dan Informatika (Menkominfo), Johnny Gerard Plate. Johnny membantah foto itumelanggarUUITEdan menyebutnya sebagai seni (Firmansyah, 2020).

Isu mengenai foto Tara meramaikan jagat dunia maya karena dugaan pelanggaran UU ITE. Tidak sedikit warganet yang membela Tara Basro dengan alasan mendukung body positivity yang dikampanyekan melalui unggahannya. Tagar \#TaraBasro pun sempat merebak di Twitter. Unggahan Tara tidak hanya mengundang reaksi warganet, namun juga menyemarakkan pemberitaan di media, salah satunya adalah kanal berita online tirto.id.

Tirto.id yang mengusung visi Jernih, Mengalir, Mencerahkan Bersama menerbitkan artikel berjudul "Foto Tara Basro dan Cara Pandang Negara yang Misoginis" (Putri, 2020). Definisi misoginis menurut Kamus Besar Bahasa Indonesia adalah orang yang membenci wanita. Sebuah judul berita yang cukup tendensius untuk portal berita online dengan lalu lintas situs tertinggi dan masuk ke dalam lima portal berita yang menjadi acuan dalam pemberitaan versi alexa.com (Gambar 1).

Tara bukanlah pesohor Indonesia pertama yang tersangkut kasus dugaan pornografi. Izabel Yahya dan Anjasmara pernah menjadi tersangka atas kasus yang kurang lebih serupa pada tahun 2006 (Ramidi, 2020). Lagi-lagi batasan pornografi yang dianggap kabur menjadi alasan pembenaran tindakan ekspos tubuh secara berlebihan atas nama edukasi maupun seni.

Undang-undang nomor 11 tahun 2008 tentang Informasi dan Transaksi Elektronik sesungguhnya telah mengatur ketentuan mengenai batasan sesuatu hal digolongkan sebagai sebuah pornografi dalam konteks transaksi elektronik. Setu menyebut Tara Basro melanggar norma kesusilaan yang diatur dalam undang-undang ITE. Norma kesusilaan terkait erat dengan norma kepatutan bertingkah laku dalam pergaulan masyarakat yang berasal dari hati nurani manusia (Kanter dan Sianturi dalam Christianto, 2017; Saleh, 1987). Implementasi mengenai definisi mengenai kepatutan ini sangatlah subjektif. Persepsimengenai kepatutan, terbentuk atas nilai-nilai yang dianut oleh setiap orang berdasarkan pengaruh dari pendidikan, lingkungan, budaya, serta wawasan masingmasing, dan media sangat berperan dalam membentuk wawasan tersebut. Melalui narasinya, media menyisipkan ideologinya terhadap sebuah 


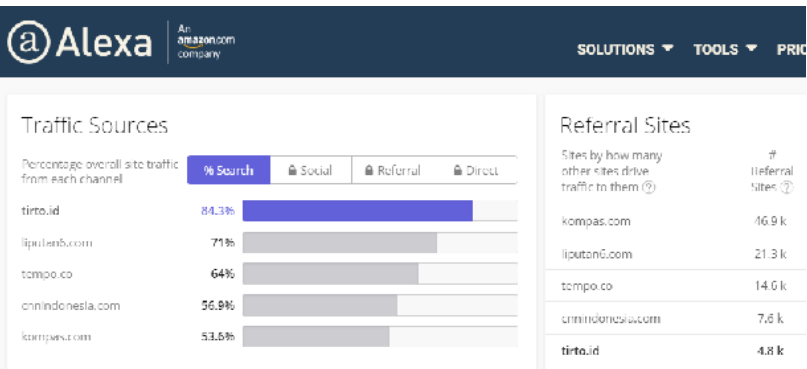

Gambar 1 Lima besar portal pemberitaan dengan lalu lintas situs tertinggi dan yang menjadi acuan pemberitaan di Indonesia

Sumber: alexa.com, (diakses pada tanggal 8 Juni 2020)

diskursus. Menjadi pertanyaan apabila media mengambil posisi untuk menegasikan sisi pornografi dalam unggahan tersebut. Ada norma kesusilaan yang dapat bergeser melalui framing media dalam isu foto kontroversial Tara Basro.

Foto tanpa busana Tara menyebabkan berlangsungnya sebuah kontestasi nilai antara body positivity atau pornografi. Sebagian pihak berdalih itu merupakan edukasi, sebagian lagi menyetujui bahwa itu pornografi. Sangat menarik melihat bagaimana media menempatkan diri dalam menyisipkan nilai-nilai dalam sajian pemberitaan.

Tahun 2019, Menteri Pemberdayaan Perempuan dan Perlindungan Anak, Yohana Yembise menyebut bahwa Indonesia darurat pornografi. Yohana terus menyerukan pentingnya melindungi anak-anak dari bahaya pornografi. Koordinator Nasional ECPAT Indonesia, Ahmad Sofian, pada tahun 2018 menyebutkan adanya peningkatan kasus kriminal yang berkaitan dengan eksploitasi anak dari waktu ke waktu, khususnya terkait penyebarluasan gambar pornografi yang dibuat sendiri oleh remaja dan tersebar secara online (Felisiani, 2019). Fakta ini mengindikasikan pornografi merupakan isu serius yang pencegahan dan edukasi mengenainya harus didukung oleh semua pihak. Dengan mengaminkan foto tanpa busana Tara sebagai body positivity, alih-alih sebuah edukasi, media bisa membuat hal yang sebaliknya terjadi. Posenya dapat ditiru dan dilihat sebagai sebuah kewajaran oleh yang orang-orang yang belum teredukasi dengan baik atas nama body positivity. Dalam skala yang lebih besar, dapat terjadi pergeseran definisi norma kesusilaan dari sejumlah besar khalayak.

Menurut Edelman (1993), realitas yang dipahami seseorang bergantung pada bingkai (framing) dan penafsiran yang diberikan pada realitastersebut. Sebuahrealitasyang dikonstruksi dengan bingkai tertentu dapat menghasilkan pemahaman yang berbeda bagi khalayak. Framing merupakan proses penggunaan perspektif tertentu, yang diejawantahkan dengan menggunakan teknik pemilihan kata dalam pemberitaan yang menandakan bagaimana fakta atau realitas dipahami (Edelman, 1993).

Fairclough melihat bahasa sebagai praktik kekuasaan. Wacana, menurutnya memiliki tiga efek. Pertama, wacana memberikan andil dalam mengkonstruksi identitas sosial dan posisi subjek. Kedua, wacana membantu mengkonstruksi relasi sosial di antara orangorang. Ketiga, wacana memberikan kontribusi dalam mengkonstruksi sistem pengetahuan dan kepercayaan. Ketiga efek ini berkontribusi dalam transformasi masyarakat (Eriyanto, 2001).

Dalam kasus ini, media memiliki kuasa melalui teksnya untuk mengarahkan publik. Eriyanto (2002) menyebut ini sebagai mobilisasi massa, sebuah strategi agar khalayak memiliki pandangan yang sama atas sebuah isu, dengan menggunakan metode framing berita. Hal ini diamini dengan beberapa model mengenai opini publik yang menyebutkan bahwa penyajian suatu isu di media memiliki peran penting dalam membentuk sikap publik. Media berperan sebagai sarana penyampaian opini sekelompok elit kepada publik.

Terdapat beberapa penelitian yang membahas framing maupun menganalisis secara kritis pemberitaan diskursus seputar pornografi. Tucker (1998) meneliti framing 
terhadap pemberitaan diskursus pornografi anak dalam iklan Calvin Klein, sedangkan Fardiah, (2007) membandingkan framing dua surat kabar nasional dalam memberitakan RUU Pornografi dan Pornoaksi. Duvall (2015) menganalisis secara kritis diskursus media seputar isu selebriti dunia yang menyusui di depan publik, namun menggunakan metode semiotika. Penelitian ini menambah khasanah kajian terkait karena membongkar bagaimana tirto.id sebagai media bereputasi yang idealnya berfungsi sebagai lembaga kemasyarakatan, kemudian mengambil posisi sebagai lembaga bisnis. Selain itu, penelitian ini juga mengungkap bagaimana tirto.id membingkai isu foto kontroversial Tara Basro dalam sebuah pemberitaan serta ideologi apa yang tirto.id bawa dalam isu tersebut.

\section{Pornografi dan Kesusilaan}

Pasal 27 ayat (1) UU ITE mengkategorikan sebuah substansi sebagai pornografi berdasarkan adanya pelanggaran terhadap norma kesusilaan dan tidak menjabarkannya ke dalam kategori yang lebih rinci. Norma kesusilaan merupakan aturan yang menjadi acuan penentuan baik buruknya suatu perbuatan (Christianto, 2016). Norma tersebut berasal dari manusia sendiri, sehingga tidak terbatas pada sikap lahir namun juga sikap batin manusia, yang kemudian hidup dan berkembang di dalam masyarakat. Norma kesusilaan terkait erat dengan norma kepatutan bertingkah laku dalam pergaulan masyarakat yang berasal dari hati nurani manusia (Kanter dan Sianturi dalam Christianto, 2017; Saleh, 1987). Implementasi mengenai definisi mengenai kepatutan ini sangatlah subjektif. Persepsi mengenaikepatutan,terbentukatasnilai-nilaiyang dianut oleh setiap orang berdasarkan pengaruh dari pendidikan, lingkungan, budaya, serta wawasan yang mereka miliki, dan media sangat berperan dalam membentuk wawasan tersebut.

Penggunaan norma kesusilaan sebagai dasar larangan perbuatan pornografi melalui internet memberikan ruang yang luas bagi diskursus terkait hal tersebut. Terlebih, pornografi melalui internet tidak terbatas pada perbuatan tertentu saja, melainkan memiliki spektrum yang sangat beragam. Hal tersebut mengindikasikan bahwa pengkategorian sesuatu sebagai pornografi tidak didasarkan hanya pada ketentuan hukum yang berlaku melainkan juga nilai kesusilaan yang hidupdanberkembang dimasyarakat(Christianto, 2017). Semakin kuat norma kesusilaan, semakin besar kemungkinan sebuah tindakan dikategorikan sebagai pornografi. Sebaliknya, semakin longgar norma kesusilaan, semakin kecil kemungkinan sebuah tindakan yang masih abuabu, dikategorikan sebagai pornografi. Pornografi erat kaitanya dengan penggunaan media.

\section{Ideologi Media dan Ideologi Pancasila}

Ideologi media adalah ideologi yang dimiliki media sebagai sebuah institusi, yang menjadi landasan keberlangsungan media tersebut (Rusadi, 2015). Ideologi versi Marx merupakan superstruktur yang dipengaruhi oleh ekonomi sebagai basis. Di sisi lain, ideologi media versi non-marxis meyakini bahwa faktor ekonomi tidak serta merta terkait dengan politik dan kekuasaan. Pada ideologi ini, permasalahan dan perkembangan media didasarkan pada faktor permintaan dan penawaran. Dengan kata lain, media yang dikendalikan oleh hukum pasar menganut ideologi liberalisme atau ideologi pasar. Sedangkan ideologi menurut versi neomarxis yang dikemukakan oleh Althusser, merupakan hasil dari proses pengalaman dan menjadi representasi imajiner dari realitas yang menunjukkan eksistensi individu atau kelompok atau organisasi. Menurut Althusser (Rusadi, 2015), pemahaman mengenai realitas yang terdistorsi oleh struktur yang dialaminya disebut kesadaran palsu.

Penelitian ini menggunakan konsep ideologi versi non-marxis dan neomarxis. Salah satu hal penting dalam teori ideologi Althusser adalah konsepnya mengenai subjek dan ideologi. Pada intinya, ideologi dalam pandangan 
Althusser selalu memerlukan subjek dan subjek memerlukan ideologi. Ideologi merupakan hasil rumusan dari sekelompok elit. Keberlakuannya menuntut persetujuan dari bukan hanya kelompok yang bersangkutan, namun juga kelompok lain di luar kelompok elit tersebut (Rusadi, 2015).

Gagasan Althusser mengenai ideologi ini menekankan pada bagaimana kekuasaan kelompok yang dominan mengontrol kelompok yang lain. Pertanyaannya, bagaimana penyebaran ideologi ini dilakukan? Pada titik inilah, konsep hegemoni yang dipopulerkan oleh ahli filsafat politik terkemuka Italia, Antonio Gramsci, layak dikedepankan. Gramsci mengkonstruksi suatu teori yang menekankan bagaimana penerimaan kelompok yang didominasi oleh kehadiran kelompok dominan berlangsung dalam suatu proses yang damai, tanpa tindakan kekerasan. Media massa dapat menjadi sarana di mana satu kelompok mengukuhkan posisinya dan melemahkan kelompok yang lain. Hal ini bukan berarti media merupakan perwujudan kekuatan jahat yang secara sengaja merendahkan masyarakat kelas bawah. Media mengukuhkan ideologinya melalui teks-teksnya, namun dalam prosesnyaadaideologilainyangmungkintergeser, ideologi Pancasila misalnya. Sebagaimana kita ketahui, dalam media, fakta, opini maupun ilusi disajikan dalam beragam bentuk, seperti: artikel berita, film, musik ataupun talkshow.

Indonesia menganut Pancasila sebagai landasan ideologi, yang tercantum dalam pembukaan Undang-undang Dasar 1945 sebagai landasan konstitusional. Pancasila memiliki lima prinsip dasar. Nilai kesusilaan yang relevan dalam penelitian ini terkandung dalam sila kedua, yaitu Kemanusiaan Yang Adil dan Beradab yang berarti menjunjung tinggi nilai-nilai kemanusiaan, kesadaran sikap dan perbuatan manusia yang didasarkan kepada potensi budi nurani manusia dalam hubungannya dengan norma-norma dan kebudayaan umumnya. Dengan kata lain, manusia bebas keinginannya, tetapi terikat pula oleh keterbatasan dan tanggungjawabnya kepada masyarakat dan negara, serta dibatasi juga oleh lingkungannya (S, 2018).

\section{Bahasa dan Kuasa}

Ideologi memerlukan perantara bahasa untuk bisa sampai kepada orang lain, oleh karena itu kajian ideologi tidak lepas keterkaitannya dengan bahasa. Hal ini sejalan dengan Norman Fairclough yang melihat bahasa sebagai praktik kekuasaan (Fairclough, 1996). Fairclough mengemukakan teori mengenai Kuasa (Power) dari perspektif sosiolinguistik yang menyoroti hubungan kekuasaan tertentu yang muncul dari bahasa sekaligus memunculkan bahasa. Fairclough menganalogikan hal tersebut dengan konvensi dalam konsultasi tradisional antara dokter dan pasien. Dokter mengerti obat-obatan dan pasien tidak; dokter punya kewenangan menentukan masalah kesehatan pasien. Dapat dilihat di sini keputusan berada pada kontrol dokter, sedangkan pasien hanya perlu memahami dan bekerja sama. Poin pentingnya adalah sangat mungkin untuk menemukan asumsi dari bentuk bahasa semacam itu. Asumsi tersebut dinamakan ideologi, yang sangat berkaitan dengan kuasa, karena sifat alami asumsi ideologis tercantum dalam konvensi tertentu dan karenanya sifat alami dari kesepakatan itu sendiri bergantung pada relasi kuasa yang mendasari sebuah konvensi.

Teori ini bertujuan untuk melihat tiga hal dalam sebuah teks media, yaitu: 1) melihat tataran ideasional, yaitu bagaimana representasi tertentu hendak ditampilkan dalam suatu teks yang pada umumnya membawa muatan ideologis tertentu; 2) melihat konstruksi hubungan antara penulis berita dengan pembaca, dengan melihat sifat teks yang formal atau informal; terbuka ataukah tertutup; dan 3) melihat konstruksi tertentu dari identitas penulis berita dan pembaca. Pada penelitian ini, teori Fairclough mengenai kuasa yang digunakan untuk melihat ketiga hal tersebut dalam objek penelitian, sebagai landasan untuk menegaskan posisi media yang tirto.id jalankan. Dalam analisis pada dimensi praktik sosiokultural terdapat asumsi bahwa konteks sosial yang ada di luar media memengaruhi bagaimana wacana yang muncul di dalam media. Analisis 
ini memang tidak berhubungan secara langsung dengan produksi teks, namun sangat menentukan bagaimana teks diproduksi dan dipahami.

\section{Teori Framing}

Media berperan mendefinisikan bagaimana realitas dipahami dan bagaimana realitas tersebut dijelaskan dengan cara tertentu kepada khalayak. Pendefinisian tersebut tidak terbatas pada peristiwa saja, namun juga melibatkan aktor-aktor sosial. Dalam hubungannya dengan ideologi, media memiliki fungsi menjaga dan mengontrol keberlangsungan nilai dan pandangan kelompok. Batas budaya menjadi kunci dalam menjalankan hal tersebut dan sangat penting untuk mendefinisikan terlebih dahulu pandangan dan nilai-nilai budaya tersebut agar dapat diterima dan diyakini keberadaannya sehingga masyarakat dapat terintegrasi ke dalam sebuah tata nilai yang sama. Di sinilah media berfungsi dalam menentukan mana yang benar, kontroversial dan menyimpang melalui konstruksi realitas yang dibangunnya.

Gambar 1 merupakan sebuah ilustrasi yang digagas oleh Daniel Hallin (Shoemaker \& Reese, 2014) untuk membantu menjelaskan bagaimana sebuah berita ditempatkan ke dalam sebuah bidang atau peta ideologi. Dunia jurnalistik dikelompokkan ke dalam tiga bidang, yaitu bidang penyimpangan (sphere of deviance), bidang kontroversi (sphere of legitimate controversy) dan bidang konsensus (sphere of consensus). Masing-masing bidang menjelaskan bagaimana wartawan memahami dan menempatkan sebuah peristiwa ke dalam keseluruhan peta ideologis. Sebuah peristiwa dapat dibingkai dan dimaknai sebagai penyimpangan, dapat pula diperlihatkan sebagai kontroversi atau malah sebuah konsensus. Dalam hal penyimpangan, suatu peristiwa, gagasan atau perilaku tertentu dipinggirkan dan dianggap menyimpang berdasarkan nilai yang dipahami bersama oleh anggota berbagai komunitas. Foto Tara disebut menyimpang oleh media yang sepakat dengan pendapat Juru Bicara Kominfo, meskipun Tirto.id tidak berpendapat demikian.

Bidang yang kedua adalah bidang kontroversi. Pada bidang ini kesepakatan antar anggota komunitas terbagi dan masih diperdebatkan. Wilayah yang paling dalam adalah bidang konsensus. Bidang ini menunjukkan bagaimana peristiwa tertentu dipahami dan disepakati sebagai realitas yang sesuai dengan nilai-nilai kelompok. Dalam praktiknya, media mampu dan sangat berperan dalam memobilisasi sebuah isu untuk berpindah bidang. Hal ini lah yang berusaha diperlihatkan dalam penelitian ini.

Pembagian area ke dalam bidang-bidang ideologis semacam ini dapat digunakan untuk menjelaskan bagaimana peristiwa yang sama dapat dijelaskan secara berbeda. Hal tersebut dikarenakan kerangka yang dipakai untuk menjelaskan berbeda sesuai masyarakat atau komunitas yang relevan. Dalam hal ini media memiliki kemampuan menjelaskan dan meletakkan sebuah peristiwa dalam bidang yang mereka inginkan dengan cara membuat seleksi, memilih peristiwa tertentu yang ditonjolkan, serta melakukan pembingkaian (framing) (Eriyanto, 2002).

Murray Edelman (1993) mensejajarkan framing sebagai kategorisasi, yaitu penggunaan perspektif tertentu dengan pemakaian katakata tertentu yang menentukan bagaimana sebuah realitas dipahami. Kategori tersebut

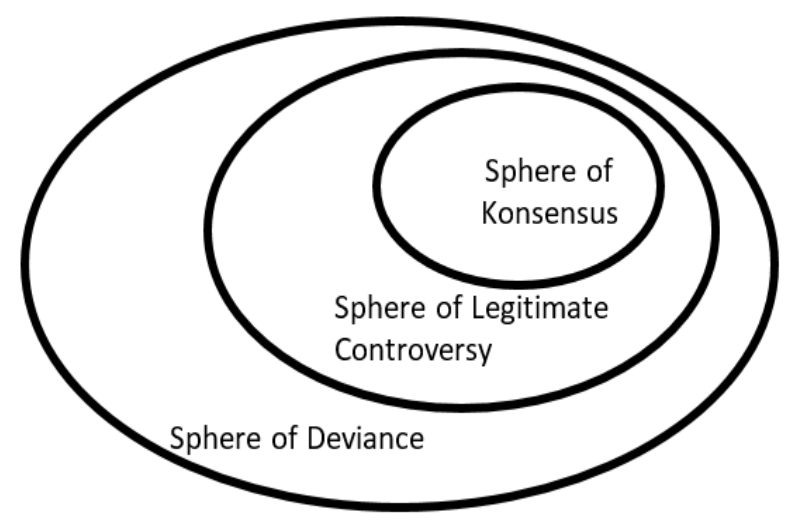

Gambar 1 Peta Ideologi Berita Hallin Sumber: Shoemaker \& Reese, (2014) 
bukan semata persoalan teknis, melainkan juga berperan dalam menentukan bagaimana suatu peristiwa dijelaskan dan diarahlan. Dalam praktik pemberitaan media, kategorisasi dalam sebuah peristiwa dengan melakukan berbagai upaya untuk mengarahkan pemberitaan menuju kategorisasi yang diinginkan. Misalnya pemilihan narasumber, kutipan yang diambil dan kalimat atau bagian mana yang dieliminasi. Pandangan Edelman mengenai kategorisasi berhubungan dengan ideology, realitas diklasifikasi, dan dikategorisasi. Penggunaan kategorisasi bukan sekadar teknis kebahasaan, melainkan merupakan masalah ideologi, yaitu bagaimana sekelompok orang diuntungkan dengan bingkai dan kategori tertentu sementara sekelompok orang yang lain dirugikan dengan bingkai tersebut.

Pada umumnya teori framing digunakan dalam paradigma konstruksionis seperti Fardiah (2007) dan Tucker (1998), namun D’Angelo (2002) dalam jurnalnya menjelaskan teori ini dapat digunakan tidak terbatas pada satu paradigma saja. Pada penelitian ini, framing digunakan dalam paradigma kritis. Beberapa di antara cendekiawan yang menggunakan paradigma kritis di antaranya adalah AkhavanMajid \& Ramaprasad (1998) dan Entman \& Rojecki (1993), yang mengklaim bahwa framing adalah hasil dari rutinitas pengumpulan berita di mana jurnalis menyampaikan informasi tentang isu dan peristiwa dari sudut pandang nilai yang dipegang oleh elit politik dan ekonomi. Peneliti yang kritis berpendapat bahwa informasi yang bertentangan dengan sikap hegemonik merupakan hal yang tidak biasa dan tidak memiliki kecenderungan untuk menumbuhkan sudut pandang alternatif pada khalayak. Peneliti mengangkat dan mengamati lebih lanjut isu ini dengan menggunakan teori framing, konsep ideologi Pancasila dan kesusilaan untuk menemukan usulan kebijakan baru mengenai pemberitaan pornografi di tirto.id. Penelitian ini bertujuan untuk mengenalisis tirto.id sebagai media bereputasi mengambil posisi sebagai lembaga bisnisalih-alih lembaga kemayarakatan, dalam memberitakan diskursus seputar pornografi.

\section{Metode Penelitian}

Penelitian ini menyelidiki framing media terhadap isu foto tanpa busana Tara Basro dalam artikel berita tirto.id sebagai objek penelitian, serta membongkar implikasi yang menyertainya dengan menggunakan pendekatan kualitatif dan paradigma kritis. Analisis Wacana Kritis (CDA) Fairclough digunakan sebagai metode analisis dengan konsep nilai kesusilaan, serta teori framing dan konsep ideologi sebagai pisau dalam menganalisis artikel berjudul "Foto Tara Basro dan Cara Pandang Negara yang Misoginis". CDA menambahkan kedalaman ke dalam penelitian dengan melangkah lebih dari sekadar "merangkum apa yang media tulis mengenai suatu isu" menjadi "bagaimana media menuliskan suatu isu" (Richardson dalam Guzman, 2016).

Pertama, dalam melakukan analisis di level teks, peneliti menggunakan teknik pengumpulan data berupa analisis naskah sintagmatis. Peneliti mengidentifikasi representasi, relasi, dan identitas yang digunakan oleh penulis dalam artikel berita. Di tahap ini, peneliti menghubungkan temuan analisis dan mengidentifikasi bingkai yang digunakan dengan teori framing dan ideologi. Analisis selanjutnya adalah level praktik diskursif. Peneliti melakukan wawancara mendalam sebagai teknik pengumpulan data. Informan sebagai subjek penelitian merupakan penulis artikel berita dari tirto.id, yang menjadi fokus penelitian ini. Analisis pada level praktik diskursif dilakukan untuk mengetahui bagaimana berita tersebut diproduksi dan dikonsumsi.

Tahap analisis selanjutnya adalah pada level sosiokultural. Penjabaran analisis di level teks dan praktik diskursif dikaitkan dengan konteks sosial politik dengan memeriksa objek, atribut dan frame yang disajikan. Peneliti mengumpulkan data melalui penelusuran literatur yang relevan dengan tema penelitian. Sejalan dengan teori 
framing, CDA melihat diskursus sebagai sesuatu yang dikonstruksi yang didukung oleh kekuasaan.

Tirto.id dipilih di antara ratusan portal berita online karena menjadi portal berita dengan lalu lintas pengunjung tertinggi berdasarkan alexa. com. Tirto.id juga menjadi lima besar portal berita online yang dijadikan rujukan dalam pemberitahuan sehingga menjadikannya sebagai portal berita online yang memiliki power yang tidak dapat dipandang sebelah mata. Terkait isu foto kontroversial Tara, tirto.id menerbitkan empat artikel, artikel dengan judul "Foto Tara Basrodan CaraPandangNegarayang Misoginis" dipilih sebagai unit analisis karena judulnya yang tendensius dan mengundang perhatian.

\section{Hasil Penelitian dan Pembahasan \\ Teks}

Aspek pertama dalam analisis teks adalah representasi. Representasi diamati pada tingkat kosakata, kalimat dan antar kalimat. Pada artikel, kosakata yang menggambarkan tindakan Tara menggunakan konotasi positif, seperti "mencintai tubuh", "percaya diri", "menginspirasi", "melawan stigma", dan sebagainya. Sebaliknya, kosakata yang merujuk pada Kominfo cenderung tendensius. Label "terburu-buru menilai", "misoginis", adalah beberapa di antaranya.

Melalui kata-kata terlihat bahwa tindakan Tara digambarkan sebagai sebuah edukasi positif yang menginspirasi perempuan lain untuk lebih percaya diri. Tara bak pahlawan yang melawan stigma standar dan berani menunjukkan dirinya apa adanya. Sebaliknya, karena Tara adalah pahlawan, maka Kominfo merupakan penjahatnya, yang terburuburu menilai, berpikir mesum, misoginis dan suka menyalahkan tubuh perempuan.

Representasi antar kalimat dalam teks dapat diketahui melalui penempatan pernyataanpernyataan partisipan pada artikel. Penulis berita menunjukkan dukungannya terhadap isu edukasi body positivity versi Tara dengan menempatkan pernyataan juru bicara Kominfo pada bagian tengah artikel, dikepung oleh pernyataan Tara dan Joko Anwar, di bagian awal, serta pernyataan Damar Juniarto dan Tunggal Pramesti pada akhir berita. Hal ini menempatkan posisi Setu sebagai juru bicara Kominfo sebagai pihak yang lemah, terkesan tidak tahu konteks, pembenci wanita dan berpikiran mesum. Selain itu jumlah partisipan yang sejalan dengan gagasan penulis berita dan dihadirkan dalam artikel seolah menjadi legitimasi tindakan Tara. Hal ini sejalan dengan konsep ideologi versi neomarxis yang menyatakan bahwa ideologi merupakan hasil dari proses pengalaman dan menjadi representasi imajiner dari realitas yang menunjukkan eksistensi individu atau kelompok atau organisasi (Rusadi, 2015).

Jika representasi berhubungan dengan bagaimana seseorang, kelompok, kegiatan, tindakan atau keadaan ditampilkan dalam teks, maka aspek selanjutnya adalah relasi, yang berhubungan dengan bagaimana partisipan dalam media terhubung satu sama lain dan ditampilkan dalam teks (Eriyanto, 2001). Media di sini dipandang sebagai sebuah arena sosial di mana semuakelompok, golongan dankhalayakyangada dalam masyarakat terhubung satu sama lain dan menyampaikan versi pendapat serta gagasannya.

Fairclough menyebutkan tiga kategori partisipan utama dalam media, yaitu: wartawan, khalayak media, dan partisipan publik (Eriyanto, 2001). Dalam artikel, pola hubungan ketiga kategori partisipan dapat terlihat dari kalimat-kalimat berikut:

"Banyak masyarakat, terutama perempuan akhirnya dapat merasa relevan" "Unggahan tersebut mendapat banyak apresiasi dari warganet" "Mereka menganggap Tara Basro merepresentasikan diri banyak perempuan"

Kalimat-kalimat tersebut menunjukkan keberpihakan penulis berita dan masyarakat kepada Tara melalui kata relevan, apresiasi dan merepresentasikan. Sementara itu, Kominfo juga mendapatkan komentar dari perwakilan tokoh dalam masyarakat, namun dengan sentimen yang berkebalikan dari Tara, seperti berikut ini: 
"Tunggal berpandangan pernyataan Kominfo tersebut merupakan cara pandang misoginis yang lagi-lagi menyalahkan tubuh perempuan" "Untuk saya yang tidak berpikir mesum, foto itu tidak sensual. "DirekturEksekutifSAFENetDamarJuniarto menganggap Kominfo terburu-buru menilai" "Kominfo semata hanya melihat postingan Tara Basro sebagai "teks" - sebatas ada ketelanjangan tapi luput melihat konteks". Aspek yang ketiga dari analisis teks adalah identitas. Fairclough menekankan untuk melihat bagaimana identitas wartawan ditampilkan dan dikonstruksi dalam teks pemberitaan (Eriyanto, 2001). Yang menarik adalah bagaimana wartawan menempatkan dan mengidentifikasi dirinya dengan isu yang dia tulis. Identitas ini menentukan bagaimana teks dibuat, bagaimana pertanyaan ditujukan kepada narasumber dan bagaimana bahan-bahan tersebut diramu menjadi berita. Identitas bukan hanya dilekatkan, tetapi juga bagaimana partisipan publik serta khalayak diidentifikasi. Tabel 1 memperlihatkan penulis dalam artikel berita ini mengidentifikasi dirinya dengan Tara danklaimedukasi bodypositivity-nya melalui keterangan pembuka serta penutup berita.

Merujuk pada hasil analisis teks pada tahap mikro, didapati bahwa penulis mengkategorikan isu foto Tara Basro sebagai sebuah edukasi body positivity. Kategorisasi yang sudah diatur sedemikian rupa sejak awal, mengarah kepada hal-hal lain, seperti narasumber yang diwawancarai, kutipan yang dicantumkan, semua mengarah pada bingkai "Foto Tara Basro sebagai edukasi body positivity" sebagaimana yang disebutkan oleh Edelman (Eriyanto, 2002). Peristiwa yang digambarkan dalam berita adalah Tara Basro sedang melakukan perjuangan mulia melawan stigma standar kecantikan dan dielu-elukan oleh masyarakat Indonesia. Perjuangan Tara Basro sangatlah penting karena berperan dalam mempengaruhi wanita Indonesia untuk lebih mencintai diri sendiri.

Hasil pemingkaian tersebut, label "pornografi" yang diberikan oleh Kominfo serta merta terbantahkan. Tidak hanya itu, posisi Kominfosemakintersudutdenganpenyebutannya sebagai misoginis. Dari teks pula dapat ditarik sebuah bingkai lagi, yaitu "Kominfo Abai Konteks". Merujuk pada penjabaran tersebut, peneliti mempertanyakan lebih lanjut mengenai: 1) kebenaran Kominfo mengabaikan konteks; 2) Pentingnya isu body positivity untuk diedukasi, terlebih dengan menggunakan foto tanpa busana oleh pesohor negeri. Hal ini dijelaskan melalui analisis pada praktik diskursif dan sosiokultural.

\section{Praktik Diskursif}

Diawali dengan ramainya pembicaraan warganet di dunia maya membahas unggahan foto kontroversial Tara pada tanggal 2 Maret, tim redaksi tirto.id memutuskan untuk menyusun pemberitaan terkait hal tersebut. Hal ini diketahui berdasarkan wawancara dengan informan. Lebih lanjut informan menuturkan bahwa framing berita yang dilakukan merujuk pada arah keberpihakan warganet terhadap isu foto kontroversial Tara. Informan menyatakan bahwa selama dua hari, berita tersebut sempat masuk ke dalam berita teratas tirto.id sebelum akhirnya tertutupi oleh berita mengenai COVID-19 yang saat itu baru merebak di Indonesia.

Saat sesi wawancara, peneliti menanyakan mengenai narasumber berita yang sebagian besar pro kepada tindakan Tara. Informan menjawab

Tabel 1 Identifikasi Penulis Berita Dengan Partisipan

\begin{tabular}{lll}
\hline Judul berita & "Foto Tara Basro dan Cara \\
& $\begin{array}{l}\text { Pandang Negara } \\
\text { Misoginis" }\end{array}$ \\
Keterangan & $:$ & "Kominfo dianggap hanya \\
Pembuka & $\begin{array}{l}\text { melihat 'teks' ketelanjangan } \\
\text { dalam foto Tara Basro tanpa } \\
\text { melihat konteksnya: edukasi }\end{array}$ \\
& $\begin{array}{l}\text { bodypositivity." } \\
\text { Keterangan } \\
\text { Penutup }\end{array}$ & $\begin{array}{l}\text { pody positivity mendorong } \\
\text { percaya diri atas tubuhnya." }\end{array}$ \\
\hline
\end{tabular}

Sumber: tirto.id. (diakses pada tanggal 8 Juni 2020) 
bahwa hal itu bukanlah hal yang disengaja. Pada awalnya informanhanyaberniat untukwawancara kepada pihak-pihak yang diharapkan bersikap netral, namun ternyata pendapat narasumber sejalan dengan framing yang diberikan. Dalam proses naik tayang pun, berita tidak mendapat banyak revisi karena status informan yang merupakan penulis dan berperan sebagai editor.

Hal ini terkait dengan peta ideologi Daniel Hallin bahwa isu foto Tara Basro ini masuk di dalam bidang kontroversi. Ada yang menolak, namun tidak sedikit yang mendukung. Penulis berita memastikan dua kutub ini terakomodir di dalam berita untuk mempertahankan reliabilitas berita. Penulis berita menunjukkan kuasa media untuk mengkonstruksi realita bahwa foto tanpa busana Tara adalah sebuah body positivity alihalih pornografi, meskipun masuk ke dalam bidang kontroversi, melalui bahasa. Hal itu dilakukan dengan bingkai "Kominfo abai Konteks" dan "Foto Tara bentuk Edukasi Body positivity". Peneliti melihat hal ini sebagai bentuk ideologi liberal mengingat Indonesia adalah negara berideologi Pancasila dengan sila keduanya: "Kemanusiaan yang adil dan beradab". Jelas, foto tanpa busana tidak termasuk dalam kategori beradab yang dimaksudkan sila kedua Pancasila tersebut. Berbagai alasan yang dibuat bertujuan untuk membenarkan framing itu. Ideologi liberal yang diidentifikasi tersebut juga ditunjukkan berdasarkan hasil wawancara dengan informan, sebagai berikut: "Ini negara kok gini banget. Memandang... (jeda) Apa ya? Cara pandangnya masih misoginis gitu-gitulah. Kayaknya kita juga ngeliat animo di medsos sih. Tapi kita kan akhirnya punya sudut pandang sendiri kan ini apa yang bisa diangkat, oh ternyata negara tu masih mandang yang kayak gini-gini sebagai pornografi"(Wawancara peneliti dengan informan X, 18 Mei 2020) Informan juga menyebutkan bahwa berita tersebut menaikkan rating yang cukup tinggi dari pembaca tirto.id. Hal ini sejalan dengan konsep ideologi versi non-marxis yang menyebutkan bahwa perkembangan media didasarkan atas hukum permintaan dan penawaran, dengan kata lain sesuai dengan kebutuhan khalayak.

\section{Praktik Sosiokultural}

Merujuk pada peta ideologi Hallin, dari bidang kontroversi dapat terlihat bahwa media bermaksud membawa ini menuju bidang konsensus. Hal ini dapat dikatakan hampir berhasil, karena beberapa hari kemudian Menteri Kominfo, Johnny Plate membantah pernyataan juru bicara Kementeriannya dengan menyebut bahwa foto tanpa busana Tara bukanlah pornografi melainkan seni.

Pembahasan mengenai foto Tara seharusnya selesai karena Kominfo telah mencabut pernyataannya, dan Tara sendiri pun sudah menghapus foto tersebut. Tidak ada yang melanggar undang-undang dan tidak ada yang tersandung ranah pidana. Implikasinya tidaklah sesederhana itu karena dapat menjadi preseden di kemudian hari. Ideologi media dalam hal ini tidak sejalan dengan Pancasila sebagai landasan ideologi bangsa Indonesia, dengan melakukan penggeseran nilai-nilai kesusilaan.

Sederhananya foto tanpa busana Tara saat ini berada dalam kegamangan penilaian, apakah merupakan perbuatan yang baik, ataukah bukan. Merujuk pada definisi norma susila, sebagai aturan yang menjadi acuan penentuan baik buruknya suatu perbuatan (Christianto, 2016), penentuan baik buruk ini menjadi indikator seberapa kuat norma susila dipegang oleh masyarakat. Dengan menyebut sebuah foto tanpa busana sebagai sebuah edukasi, maka maknanya menjadi baik, dan dengan demikian bergeserlah norma kesusilaan tersebut menjadi lebih lemah. Sebaliknya dalam kasus yang sama pada tahun 2006, Izabel Yahya dan Anjasmara ditetapkan sebagai tersangka kasus pornografi. Tara memang bermaksud baik dalam mengunggah fotonya, namun sebagaimana disebutkan Ting-Toomey dan Chung (2012) komunikasi bukan hanya tentang niat, namun juga konsekuensi atau dampak yang menyertainya. 
Implikasi dari norma kesusilaan yang bergeser adalah pemakluman yang besar terhadap tindakan-tindakan serupa di kemudian hari, dan membuatnya menjadi hal yang lumrah. Di satu sisi Menteri Yohanna menyebutkan bahwa pornografi anak di Indonesia sudah masuk dalam tingkat yang gawat, namun di sisi lain, gambar atau tayangan yang mengumbar tubuh dianggap sebagai hal yang lumrah. Dua hal yang sangat kontradiktif.

Saat disinggung mengenai kemungkinan dampak pembiasaan tersebut dan anak-anak yang mungkin mengikuti jejak Tara, informan menjawab bahwa tugas orangtua untuk menjaga anak-anaknya agar tidak mengakses hal yang negatif di Internet. Argumen informan didukung oleh hasil penelitian Claretta \& Arianto (2018) mengenai implementasi social co-access, yaitu pendampingan akses internet anak oleh orangtua. Selain itu, informan juga menekankan urgensi negara memperjelas definisi norma kesusilaan, serta memasukkan pendidikan seks ke dalam kurikulum pendidikan, agar khalayak terutama anak-anak lebih melek dan teredukasi, terutama dalam hal-hal yang menjurus ke pornografi. Konsep media literasi pada anak yang diusulkan oleh informan, didukung oleh rekomendasi penelitian Tripambudi dan Novianti (2018). Sekilas hal tersebut memang sebuah gagasan ideal untuk menghindarkan bahaya pornografi terhadap anak-anak, namun sebaliknya bukan merupakan hal yang mudah untuk dilakukan dan memerlukan waktu yang tidak sebentar.

Dibandingkan itu, menghindarkan anak-anak dari pornografi dapat dilakukan dengan tindakan sesederhana tidak melakukan edukasi dengan gambar yang kurang pantas, selain memang orangtua juga harus membatasi penggunaan internet oleh anak. Bahkan edukasi mengenai seks tidak melulu harus dengan gambar yang vulgar. Hal tersebut kembali lagi kepada nilai yang dianut oleh masing-masing orang, dan nilai kesusilaan yang masih kuat mengakar. Idealnya, dibandingkan mengutamakan posisinya sebagai lembaga bisnis, media mengemban tugas mulia untuk dapat memberdayakan kehidupan masyarakat. Media takluk pada tuntutan pasar dengan melakukan penggeseran nilai kesusilaan yang dapat berdampak kepada moral bangsa dan dengan demikian melemahkan fungsinya sebagai lembaga kemasyarakatan.

Berdasarkan hasil analisis, peneliti memperoleh informasi bahwa tirto.id menganut ideologi liberal, lebih permisif dalam memberitakan pornografi, dan mengambil posisi sebagai lembaga bisnis alih-alih lembaga kemasyarakatan. Hal ini sejalan dengan penelitian Aziz (Aziz, 2018) yang menemukan bahwa media di Indonesia belum bisa mewujudkan ruang publik yang leluasa karena dijadikan sebagai komoditas bisnis yang bisa meraup keuntungan dalam jumlah besar. Pemilik media hanya merilis berita yang sesuai dengan kepentingan media.

Peneliti menemukan hal yang berlawanan dengan topik sejenis, di mana media menjalankan perannya sebagai lembaga kemasyarakatan ketimbang bisnis (Duvall, 2015; Fardiah, 2007; Tucker, 1998). Penelitian Fardiah (2007) menemukan bahwa institusi media yang berbeda memberitakan dirkusus seputar RUU Pornografi dan Pornoaksi secara berbeda pula. Harian Kompas bersikap kontra terhadap pasal dalam RUU pornografi yang dinilai bias, sedangkan Harian Republika menekankan urgensi meresmikan RUU tersebut. Fardiah tidak meneliti lebih lanjut keterkaitan sikap dua surat kabar tersebut dengan ideologi media.

Penelitian Duvall (2015) dan Tucker (1998), mendapati bahwa media terlalu kaku dan tendensius dalam menilai sebuah isu yang menjurus ke arah pornografi. Tucker (1998) menemukan bahwa media mengkonstruksi penilaian negatif sebuah iklan melalui framing pornografi anak. Media juga mengatasnamakan publik untuk mengecam iklan tersebut. Duvall (2015) dari perspektif feminis menyoroti kemunafikan media yang menganggap lumrah eksibisi payudara baik oleh pesohor maupun 
nonpesohor, namun memandang sebaliknya terhadap eksibisi payudara oleh pesohor di hadapan publik dalam konteks menyusui. Duvall (2015) menggunakan pendekatan semiotika untuk melakukan penelitiannya. Kedua penelitian ini sama-sama meneliti media di Amerika namun tidak membicarakan kaitan antara diskursus di media dengan ideologi yang digunakan oleh media tersebut.

\section{Simpulan}

Hasil penelitian menunjukkan bahwa tirto.id menggunakan posisi institusi media sebagai lembaga bisnis ketimbang lembaga kemasyarakatan di tengah masyarakat Indonesia yang sebenarnya membutuhkan sosok media sebagai lembaga kemasyarakatan. Hal ini dapat dijelaskan melalui dua framing yang teridentifikasi dalam artikel tersebut, yaitu "Foto Tara sebagai bentuk Edukasi Body positivity" dan "Kominfo yang Abai Melihat Konteks" serta penegasan kembali oleh informan bahwa tirto.id menjadikan animo masyarakat sebagai salah satu acuan penyusunan berita. Framing tersebut menunjukkan ideologi yang dipegang tirto.id adalah ideologi pasar, yang sejalan dengan konsep ideologi nonmarxis. Lebih lanjut lagi ideologi neomarxis teridentifikasi dalam penyajian realitas yang menunjukkan eksistensi individu atau kelompok mayoritas yang dalam hal ini adalah pasar. Di sisi lain, ideologi tersebut bertentangan dengan sila kedua Pancasila sebagai ideologi negara dan berpotensi menggeser nilai kesusilaan sehingga tindakan serupa berpotensi dianggap lumrah di kemudian hari. Substansi penelitian ini memberikan pemahaman kepada khalayak bahwa media bereputasi tidak identik dengan idealisme sebagai lembaga kemasyarakatan, oleh karena itu sikap kritis pembaca dibutuhkan dalam membaca diskursus yang disajikan media dalam berita.

\section{Acknowledgent}

Peneliti mengucapkan terima kasih kepada Prof. Ibnu Hamad dan Dr. Udi Rusadi atas komentar, saran dan masukannya dalam penelitian ini.

\section{Daftar Pustaka}

Akhavan-Majid, R., \& Ramaprasad, J. (1998). Framing and Ideology: A Comparative Analysis of U.S. and Chinese Newspaper Coverage of the Fourth United Nations Conference on Women an the NGO Forum. Mass Communication and Society, 1(3-4), 131-152. https://doi. org/10.1080/15205436.1998.9677853

Aziz, Muhammad Hilmy. (2018). Konglomerasi Media Antara Konvergensi Media dan Kebebasan Berpendapat. Jurnal Ilmu Komunikasi, 16(3), 209-226. Retrieved from http://jurnal.upnyk.ac.id/index. $\mathrm{php/komunikasi/article/view/3203}$ Christianto, H. (2016). Norma Kesusilaan sebagai Batasan Pornografi menurut UU No . 44 Tahun 2008. 44. https:// doi.org/10.13140/RG.2.1.4128.6169

Christianto, H. (2017). Norma Kesusilaan Sebagai Dasar Pencelaan Perbuatan Pidana Pornografi Melalui Internet: Suatu Reorientasi. Semnas Sipendikum FH UNIKAMA 2017, 1, 183-197. Claretta,D.,\&Arianto,I.D.(2018).Pendampingan Ibu pada Anak Dalam Penggunaan Internet. Jurnal Ilmu Komunikasi, 16(2), 129-137. Retrieved from http://jurnal.upnyk.ac.id/ index.php/komunikasi/article/view/2689

D'Angelo, P. (2002). News Framing as a Multiparadigmatic Research Program: a Response to Entman. Journal of Communication, 52(4), 870-888. https://doi. org/10.1111/j.1460-2466.2002.tb02578.x

Duvall, S.-S. (2015). Not "Simply the Breast." Feminist Media Studies, 15(2), 324-340. https://doi.org/ $10.1080 / 14680777.2014 .919334$

Edelman, M. (1993). Contestable Categories and Public Opinion. Political Communication, 10(3), 231-242. https:// doi.org/10.1080/10584609.1993.9962981

Entman, R., \& Rojecki, A. (1993). Freezing out the public: Elite and media framing of the U.S. anti-nuclear movement. Political 
Communication, 10(2), 155-173. https:// doi.org/10.1080/10584609.1993.9962973

Eriyanto. (2001). Analisis Wacana: Pengantar Analisis Teks Media (N. Huda (ed.); 1st ed.). LKiS. Eriyanto.(2002). AnalisisFraming(1sted.).LKiS. Fairclough, N. (1996). Language and Power. In C. N. Candlin (Ed.), Language and Power. Longman Publishing. Fardiah, D. (2007). Polemik Rancangan UndangUndang Anti Pornografi \& Pornoaksi (RUU-APP). Mediator, 8(1), 131-150.

Felisiani, T. (2019). Menteri Yohana: Indonesia Darurat Pornografi, Kita Harus Jaga Anak-anak. Tribunnews. https://www. tribunnews.com/nasional/2019/09/06/ menteri-yohana-indonesia-daruratpornografi-kita-harus-jaga-anak-anak

Firmansyah, M. (2020, March 11). Foto Tara Basro: Bias antara pornografi dan kampanye body positivity. Alinea. https://www.alinea. id/gaya-hidup/foto-tara-basro-bias-antarapornografi-dan-body-positivity-b1ZJE9src Guzman,A. L. (2016). Evolution of News Frames during the 2011 Egyptian Revolution: Critical Discourse Analysis of Fox News and CNNs Framing of Protesters, Mubarak, and the Muslim Brotherhood. Journalism and Mass Communication Quarterly, 93(1), 80-98. https://doi.org/10.1177/1077699015606677

Putri, R. D. (2020, March 5). Foto Tara Basro dan Cara Pandang Negara yang Misoginis. Tirto.Id. https://tirto.id/foto-tara-basro-dancara-pandang-negara-yang-misoginis-eCRK
Ramidi. (2020). Anjasmara Jadi Tersangka Kasus Pornografi? Koran Tempo. https:// koran.tempo.co/read/metro/62668/ anjasmara-jadi-tersangka-kasus-pornografi?

Rusadi, U. (2015). Kajian Media: Isu Ideologis dalam Perspektif, Teori dan Metode (T. Subhi (ed.); first). PT. Raja Grafindo Persada. S, L. A. (2018). Perlindungan Hukum Bagi Anak dalam Perspektif Pancasila dan Bela Negara. UNIFIKASI : JurnalIlmuHukum,5(1),58-70. https://doi.org/10.25134/unifikasi.v5i1.754 Saleh, R. (1987). Kitab Undang-undang Hukum Pidana dengan Penjelasannya. Aksara Baru. Shoemaker, P. J., \& Reese, S. D. (2014). Mediating the Message in the 21st Century: A Media Sociology Perspective. In Journal of Broadcasting and Electronic Media (3rd ed., Vol. 61, Issue 1). Routledge. Silverblatt, A. (2004). Media as Social Institution. American Behavioral Scientist, 48(1), 35-41. https://doi.org/10.1177/0002764204267249

Ting-Toomey, S., \& Chung, L. C. (2012). Understanding Intercultural Communication $\left(2^{\text {nd }}\right.$ ed.). Oxford University Press. Tripambudi, S., \& Novianti, D. (2018). Model Literasi Media di Lingkungan Rumah Panti Asuhan.Jurnal Ilmu Komunikasi, 16(2), 187196.Retrievedfromhttp://jurnal.upnyk.ac.id/ index.php/komunikasi/article/view/2694 Tucker, L. R. (1998). The framing of Calvin Klein: A frame analysis of media discourse about the august 1995 Calvin Klein jeans advertising campaign. Critical Studies in Media Communication, 15(2), 141-157. https:// doi.org/10.1080/15295039809367039 